approved for the treatment of active Systemic Lupus erythematosus (SLE) patients not responding to standard of care. Data from RCTs and observational studies have demonstrated its efficacy, especially in patients with joint involvement. Focusing on this specific manifestation, the response has been also demonstrated by using Disease Activity Score on 28 joints (DAS28) (1). No data are available about the response to BLM in terms of synovitis, assessed by ultrasonography (US).

Objectives: In the present 6-months longitudinal study, we evaluated the response to BLM in SLE patients treated for joint involvement, by using clinimetric indices and US assessment.

Methods: SLE patients starting BLM in the period between August 2013 and December 2016 were prospectively examined. The present analysis was restricted to patients requiring BLM for joint involvement. A complete physical examination and US assessment were performed at baseline (TO) and after 3 (T3) and 6 months (T6). At each time, we assessed the global disease activity by Systemic Lupus Erythematosus Disease Activity Index-2000 (SLEDAI-2K) and the joint involvement activity by DAS28. US evaluation of 12 joints (I-V metacarpophalangeal, I-V proximal interphalangeal, wrist and knee bilateral) was performed to identify inflammatory features (synovial effusion and hypertrophy, power Doppler) according to the OMERACT definitions. These elementary lesions were scored according to a semi-quantitative scale $(0=a b s e n t, 1=$ mild, $2=$ moderate and $3=$ severe) and a total score, corresponding to the patient's inflammatory status $(0-216)$ was obtained by their sum.

Results: Moving from 35 SLE patients starting BLM, 14 (14 female; mean age + SD $48.4 \pm 8.6$ years; mean disease duration $\pm S D$ 255.4 \pm 124.2 months) were treated for prevalent joint involvement. At baseline, the mean DAS28 \pm SD was $4.5 \pm 1.1$, the mean SLEDAI-2K \pm SD was $6.1 \pm 1.5$ and the mean daily prednisone \pm SD was $7.8 \pm 3.5 \mathrm{mg}$. After 3 months of treatment we observed a significant reduction in mean DAS28 ( $3.1 \pm 0.8$ vs $4.5 \pm 1.1, \mathrm{P}=0.007)$ and in mean SLEDAl-2K ( $3.5 \pm 2.1$ vs $6.1 \pm 1.5, P=0.003)$ compared to baseline. The mean daily prednisone significantly decreased at $T 6(4.7 \pm 1.4$ vs $7.8 \pm 3.5 \mathrm{mg}, \mathrm{P}=0.03)$ while the rest of the therapy remained stable for 6 months. Of note, the mean total US score significantly decreased at T3 compared to T0 $(13.7 \pm 24.4$ vs $22.2 \pm 22.6, P=0.001)$. This result was maintained in 12 patients (85.7\%) after 6 months with a statistically significant difference compared to T0 (7.9 \pm 6.6 vs $22.2 \pm 22.6, \mathrm{P}=0.003$ ) (Figure 1).

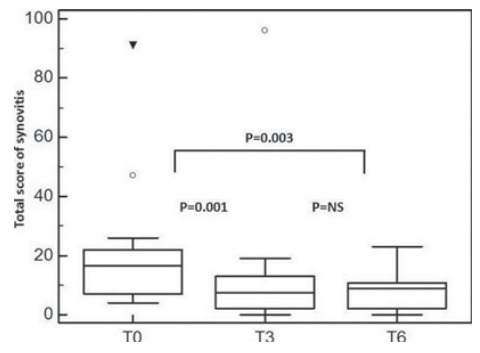

Conclusions: The results of the present study demonstrated the efficacy of BLM in SLE-related joint involvement, evaluated by SLEDAI-2K and DAS28, confirming previous data reported in the scientific literature. For the first time, we demonstrated an early response to BLM as proved by the reduction of the total US synovitis score after 3 months, reflecting the improvement of the joint inflammatory status.

References:

[1] laccarino $L$ et al. Effects of Belimumab on Flare Rate and Expected Damage Progression in Patients With Active Systemic Lupus Erythematosus. Arthritis Care Res. 2017; 69:115-123.

Disclosure of Interest: None declared

DOI: 10.1136/annrheumdis-2017-eular.4238

\section{SAT0242 MEASURES OF PERIPHERAL BLOOD B-CELL DEPLETION PREDICT RENAL RESPONSE IN PATIENTS WITH LUPUS NEPHRITIS TREATED WITH RITUXIMAB}

L.M. Gomez Mendez ${ }^{1}$, M.D. Cascino ${ }^{2}$, J. Garg ${ }^{2}$, P. Brunetta ${ }^{2}$, M. Dall'Era ${ }^{1}$, L. Dragone ${ }^{2} .{ }^{1}$ UCSF; ${ }^{2}$ Genentech, San Francisco, United States

Background: LUNAR, a randomized controlled trial, investigated the addition of rituximab (RTX) to standard of care for the treatment of lupus nephritis (LN). While this study did not meet its primary endpoint, there was an increase in partial renal response associated with RTX. Subsequent observational studies have suggested that there is variability in the degree of peripheral blood B-cell depletion in patients with SLE following treatment with RTX and that greater B-cell depletion may result in increased therapeutic efficacy.

Objectives: To assess the relationship between parameters of B-cell depletion and measures of renal response in patients treated with RTX.

Methods: We analyzed data from the LUNAR trial (registry number NCT00282347) who were treated with RTX and for whom complete CD19 measurements and renal endpoints were available $(n=70)$. We developed several parameters to assess the degree, duration and rate of depletion of CD19 counts from randomization through day 364. Complete renal response (CRR) was defined as urine protein to creatinine ratio (UPCR) $<0.5$, normal serum creatinine or, if normal at baseline, not increased by $\geq 15 \%$, and inactive urinary sediment. Spearman's correlation was used to identify associations between baseline characteristics and measures of B-cell depletion. The association between measures of B-cell depletion and CRR (at weeks 52 and 78) was examined using logistic regression adjusted for baseline UPCR. Separately, analyses were stratified by baseline anti-double stranded DNA antibody titer status (anti-dsDNA).

Results: Baseline UPCR correlated with the degree of B-cell depletion following RTX treatment by several measures (time spent at $C D 19=0$ cells $/ \mathrm{ml}[\mathrm{r}=-0.32]$; CD19 nadir $[r=0.33]$; percent change from baseline to nadir $[r=0.3])$. Measures of B-cell depletion were associated with CRR and percent change in UPCR at week 78 (Table 1). Achievement of a nadir of $\mathrm{CD} 19=0 \mathrm{cells} / \mathrm{ml}$ had an odds ratio (OR) $=5.18(95 \% \mathrm{Cl}: 1.03-26.1)$; patients who spent greater than the median percent of time at $\mathrm{CD} 19=0 \mathrm{cells} / \mathrm{ml}$ had $\mathrm{OR}=3.3(95 \% \mathrm{Cl}: 1.14-9.62)$ for $\mathrm{CRR}$ at week 78. In subgroup analyses, associations between these measures of peripheral blood B-cell depletion and renal response were strongest among patients with high baseline anti-dsDNA titer. No measures of B-cell depletion were associated with CRR at week 52

Table 1. Adjusted multivariate measures of B-cell depletion and their associations with complete renal response and percent change from baseline UPCR.

\begin{tabular}{|c|c|c|c|c|}
\hline & \multicolumn{2}{|c|}{$\begin{array}{l}\text { OR of Complete Renal Response } \\
\qquad(95 \% \mathrm{Cl})\end{array}$} & \multicolumn{2}{|c|}{$\begin{array}{l}\text { Percent change in UPCR } \\
(95 \% \mathrm{Cl})\end{array}$} \\
\hline & Week 52 & Week 78 & Week 52 & Week 78 \\
\hline $\begin{array}{l}\text { CD19 reaches } 0 \text { cells } / \mu l \text { at } \\
\text { any time point }\end{array}$ & $\begin{array}{c}2.12 \\
(0.49,9.07)\end{array}$ & $\begin{array}{c}5.18 \\
(1.03,26.08)\end{array}$ & $\begin{array}{c}-18.9 \% \\
(-42.7,4.88)\end{array}$ & $\begin{array}{c}-31.8 \% \\
(-70.7,7.01)\end{array}$ \\
\hline $\begin{array}{l}\text { Above median percent of } \\
\text { time at } 0 \text { cells/ } \mu \mathrm{l}\end{array}$ & $\begin{array}{c}1.23 \\
(0.41,3.67)\end{array}$ & $\begin{array}{c}3.32 \\
(1.14,9.62)\end{array}$ & $\begin{array}{l}-11.28 \% \\
(-31,8.5)\end{array}$ & $\begin{array}{c}-39.5 \% \\
(-68.2,-10.8)\end{array}$ \\
\hline $\begin{array}{l}\text { Area under the curve for all } \\
B \text { cell measurements in one } \\
\text { year }\end{array}$ & $\begin{array}{c}0.78 \\
(0.38,1.59)\end{array}$ & $\begin{array}{c}1.88 \\
(0.90,3.94)\end{array}$ & $\begin{array}{c}-1.87 \% \\
(-15.4,11.6)\end{array}$ & $\begin{array}{c}1.15 \% \\
(-19.6,22.6)\end{array}$ \\
\hline $\begin{array}{l}\text { For every } 30 \text { of days spent } \\
\text { at } 0 \text { cells } / \mu l\end{array}$ & $\begin{array}{c}1.11 \\
(0.89,1.38)\end{array}$ & $\begin{array}{r}1.1 \\
(0.95\end{array}$ & $\begin{array}{c}-2.7 \% \\
(-6.9,1.38)\end{array}$ & $\begin{array}{c}-6.18 \% \\
(-12.3,0.06)\end{array}$ \\
\hline Percent of visits at 0 cells $/ \mu l$ & $\begin{array}{c}1.01 \\
(0.98,1.05)\end{array}$ & $\begin{array}{c}1.03 \\
(1.00,1.06)\end{array}$ & $\begin{array}{r}-0.4 \\
(-1.06\end{array}$ & $\begin{array}{c}-1.05 \% \\
(-1.93,-0.17)\end{array}$ \\
\hline $\begin{array}{l}\text { Every increment of } 30 \text { days } \\
\text { to nadir }\end{array}$ & $\begin{array}{r}1.06 \\
(0.9,1.2\end{array}$ & $\begin{array}{r}0.92 \\
(0.78,1.0\end{array}$ & $\begin{array}{c}(-1.06,0.15) \\
-0.72 \% \\
(-3.81,2.34)\end{array}$ & $\begin{array}{c}(-1.93,-0.17) \\
1.05 \% \\
(-3.6,5.7)\end{array}$ \\
\hline $\begin{array}{l}\text { Percent change in CD19 } \\
\text { from baseline to nadir }\end{array}$ & $\begin{array}{c}0.74 \\
(0.36,1.5\end{array}$ & $\begin{array}{c}0.56 \\
(0.25,1.2\end{array}$ & $\begin{array}{c}0.01 \% \\
(-11.4,11.4)\end{array}$ & $\begin{array}{c}23 \% \\
(-0.84,46.9)\end{array}$ \\
\hline CD19 nadir & $\begin{array}{c}0.00,1.50) \\
0.49 \\
(0.12,1.94)\end{array}$ & $\begin{array}{c}0.20,1.20) \\
0.22 \\
(0.04,1.12)\end{array}$ & $\begin{array}{c}19.5 \% \\
(-2.33,41.4)\end{array}$ & $\begin{array}{c}28.4 \% \\
28.4 \% \\
(-7.06,63.8)\end{array}$ \\
\hline
\end{tabular}

$O R$, odds ratio: UPCR, urine protein to creatinine ratio.

Conclusions: Baseline UPCR was inversely correlated with the degree of peripheral B-cell depletion. B-cell depletion measures were associated with increased odds of achieving CRR and decreased UPCR at week 78 and these associations were strongest among patients with high baseline anti-dsDNA titer. These data support the exploration of high-sensitivity B-cell measurements in future studies of B-cell depleting treatments in $L N$ and suggest that longer duration of follow up may better demonstrate efficacy with B-cell depleting agents.

References:

[1] Rovin Arthritis Rheum 2012

[2] Vital Arthritis Rheum 2011.

Disclosure of Interest: L. Gomez Mendez Grant/research support from: Genentech/Roche, M. Cascino Employee of: Genentech/Roche, J. Garg Employee of: Genentech/Roche, P. Brunetta Employee of: Genentech/Roche, M. Dall'Era: None declared, L. Dragone Employee of: Genentech/Roche

DOI: 10.1136/annrheumdis-2017-eular.5412

\section{SAT0243 EXPOSURE-RESPONSE (E-R) ANALYSIS FOR SELECTION OF OPTIMAL DOSAGE REGIMEN OF ANIFROLUMAB IN PATIENTS (PTS) WITH SYSTEMIC LUPUS ERYTHEMATOSUS (SLE)}

L.C. Santiago $^{1}$, B. Wang ${ }^{1}$, P. Brohawn ${ }^{2}$, L. Wang ${ }^{2}$, G. Illei ${ }^{2}$, L. Roskos ${ }^{2}$. ${ }^{1}$ Medlmmune LLC, Mountain View; ${ }^{2}$ Medlmmune LLC, Gaithersburg, United States

Background: Anifrolumab is a fully human $\lg _{1}$ monoclonal antibody directed against subunit 1 of the type I interferon- $\alpha$ receptor (IFNAR1). It is in development for treatment of SLE.

Objectives: To support dosage selection for pivotal anifrolumab studies, using an E-R model.

Methods: In the Phase Ilb MUSE study (NCT01438489), ${ }^{1}$ adult pts with moderate to severe SLE, who had inadequate responses to standard-of-care (SOC) medications, were randomized $1: 1: 1$ to intravenous anifrolumab 300 or $1,000 \mathrm{mg}$ or placebo every 4 weeks (Q4W), in addition to SOC medications, for 48 weeks. Pts were stratified by type I interferon gene signature (IFNGS) test status (high or low) using a validated 4-gene expression assay, oral corticosteroid dosage ( $<10$ or $\geq 10 \mathrm{mg} /$ day of prednisone or equivalent), and SLE disease activity index $-2 \mathrm{~K}$ score $(<10$ or $\geq 10)$ at screening. A mechanistic targetmediated drug disposition model ${ }^{2}$ was used to describe the pharmacokinetics (PK) of anifrolumab. The dichotomous efficacy endpoint, SLE responder index [SRI (4)], was modeled using logistic regression. A dropout hazard function was used to describe voluntary withdrawals during treatment. Clinical simulations were conducted to assess dosing scenarios in virtual SLE pts.

Results: There was no PK difference between type I IFNGS test-high or -low pts (mean [standard deviation] $\mathrm{C}_{\text {trough }}$ (Day 169): 17.0 [11.5] $\mu \mathrm{g} / \mathrm{mL}$ and 23.3 [16.0] $\mu \mathrm{g} / \mathrm{mL}$, respectively). SRI (4) modeling demonstrated no anifrolumab treatment effect in type I IFNGS test-low pts compared with placebo; interpretation of this 
result may be limited by small sample size. In type I IFNGS test-high pts, a log-linear logistic model was used to describe the treatment effect of anifrolumab. Pt dropouts were more likely in nonresponders. Clinical simulations demonstrated dosages $<300 \mathrm{mg}$ would result in inadequate PK exposure and suboptimal efficacy in some pts with SLE. In contrast, simulations indicated minimal efficacy improvement for dosages $>300 \mathrm{mg}$, consistent with the Phase Ilb MUSE study outcomes.

Conclusions: Based on $\mathrm{E}-\mathrm{R}$ analyses and overall risk assessment, a 300 $\mathrm{mg}$ Q4W, intravenous dosage regimen is recommended for pivotal anifrolumab studies in pts with SLE.

References:

[1] Furie R, et al. Arthritis Rheumatol. 2017;69:376-86.

[2] Wang B, et al. Clin Pharmacol Ther. 2013;93:483-92.

Acknowledgements: Funded by Medlmmune. Medical writing support: R. Plant, QXV Comms, an Ashfield company, funded by Medlmmune.

Disclosure of Interest: L. Santiago Shareholder of: AstraZeneca, Employee of: Medlmmune LLC, B. Wang Shareholder of: AstraZeneca, Employee of: Medlmmune LLC, P. Brohawn Shareholder of: AstraZeneca, Employee of: Medlmmune LLC, L. Wang Employee of: Medlmmune LLC, G. Illei Shareholder of: AstraZeneca, Employee of: Medlmmune LLC, L. Roskos Shareholder of: AstraZeneca, Employee of: AstraZeneca

DOI: 10.1136/annrheumdis-2017-eular.3517

\section{SAT0244 A LONG-TERM FOLLOW-UP STUDY OF ALLOGENEIC MESENCHYMAL STEM CELLS TRANSPLANTATION IN PATIENTS WITH DRUG-RESISTANT SYSTEMIC LUPUS ERYTHEMATOSUS}

D. Wang ${ }^{1}$, L. Sun ${ }^{2} .{ }^{1}$ Department of Rheumatology and Immunology; ${ }^{2}$ Department of Rheumatology, The Affiliated Drum Tower Hospital of Nanjing University Medical School, Nanjing, China

Background: Allogeneic mesenchymal stem cells (MSC) transplantation showed therapeutic effect in active and refractory systemic lupus erythematosus (SLE). Objectives: To determine the long-term safety and efficacy of allogeneic MSC transplantation (allo-MSCT) in severe SLE patients refractory to previous therapies.

Methods: All consecutive SLE patients who received at least one allo-MSCT were analyzed. SLEDAI score of more than or equal to 8 or with at least one BILAG grade A or at least two BILAG grade B manifestations. All the patients were refractory to corticosteroid and/or immunosuppressive drugs treatment. Allogeneic bone marrow and/or umbilical cord derived MSCs were infused intravenously, with one million cells per kilogram of bodyweight for each infusion. The primary end point was 5 -year overall survival. Secondary end points included complete clinical remission, partial clinical remission and relapse.

Results: Eighty-one patients were enrolled and underwent allo-MSCT. Thirteen patients died within 5 years post-MSCT and the 5 -year overall survival rate was $84 \%(68 / 81)$. At 5 -year follow-up, 22 patients $(22 / 68,32 \%)$ were in complete clinical remission and another 6 patients $(6 / 68,9 \%)$ were in partial clinical remission, and the 5 -year disease remission was $41 \%$ (28/68). In total, 37 patients had achieved clinical remission (27 in complete remission and 10 in partial remission) at the 5 years visit and then 9 patients subsequently relapsed. The 5-year overall rate of relapse was $24 \%(9 / 37)$. SLEDAl scores, levels of serum albumin and complement $\mathrm{C} 3$, peripheral white blood cell and platelet numbers, as well as proteinuria levels continued to improve during the follow-up.

Conclusions: Allogeneic MSCT is safe and resulted in long-term clinical remission in severe and drug-resistant SLE patients.

Disclosure of Interest: None declared

DOI: 10.1136/annrheumdis-2017-eular.2656

\section{SAT0245 SERUM IFN GAMA MAY PREDICT THERAPEUTIC EFFECT OF MESENCHYMAL STEM CELLS TRANSPLANTATION IN SYSTEMIC LUPUS ERYTHEMATOSUS PATIENTS}

D. Wang, L. Sun. Department of Rheumatology, The Affiliated Drum Tower Hospital of Nanjing University Medical School, Nanjing, China

Background: Umbilical cord (UC) derived mesenchymal stem cells (MSCs) show immunoregulatory properties on various immune cells and display clinical effect on lots of autoimmune disease like systemic lupus erythematosus (SLE).

Objectives: The aim of this study is to investigate the effect of SLE environment on UC MSCs and to observe the possible serum biomarker to predict the therapeutic effect.

Methods: UC MSCs were co-cultured with peripheral blood mononuclear cells (PBMC) from active lupus patients at a ratio of 1:4. The proliferation, apoptosis and surface markers of UC MSCs were observed. UC MSCs functional molecules were assessed by real-time PCR and the signaling pathways were analyzed by western blot. Different recombinant cytokines were used to stimulate UC MSCs in vitro and the functional factors were determined by real-time PCR. In the last, twenty-six patients with SLE, refractory to conventional therapies, were given UC MSCs transplantation. The clinical effect was followed-up for one year to classify responder and non-responder groups, and baseline serum cytokines were analyzed by ELISA.
Results: The co-culture of lupus patients PBMC had no effect on UC MSCs surface markers and apoptosis, but promoted MSCs proliferation. Lupus PBMC were more prone to stimulate UC MSCs to secret VEGF as well as CXCL-12, compared to PBMC from normal controls. Furthermore, lupus PBMC activated Akt, IKB and Stat5 signaling pathways in UC MSCs but not affect Erk1/2 and Smad1/5/8 pathways. When stimulated by different cytokines, we found that interferon $\gamma(\mathrm{IFN}-\gamma)$ was still the most important cytokine to induce IDO1 as well as IDO2 productions in UC MSCs; both had dose-dependent manners. Moreover, our clinical study showed that baseline higher levels IFN- $\gamma$ might predict a good response to MSCs transplantation in active lupus patients.

Conclusions: Baseline IFN- $\gamma$ levels may predict clinical response to MSCs therapy for active lupus patients, which will help us to choose appropriate patient for clinical transplantation.

Disclosure of Interest: None declared

DOI: 10.1136/annrheumdis-2017-eular.2661

\section{SAT0246 EXPLORER STUDY: RITUXIMAB USE IN SYSTEMIC LUPUS ERYTHEMATOSUS, A NEW LOOK ON OLD DATA}

M. Scherlinger, C. Carcaud, M.E. Truchetet, P. Dufau, L. Couzy, J. Seneschal, T. Barnetche, E. Lazaro, C. Richez. Fhu Acronym, CHU de Bordeaux, Bordeaux, France

Background: Even if randomized trials EXPLORER and LUNAR failed to prove the superiority of rituximab versus placebo in patients with systemic lupus erythematosus, several encouraging indications as refractory lupus nephritis and new clinical trials renewed interest for this molecule.

We hypothetized that SLE response criteria used in EXPLORER were not sensible enough to show rituximab efficacy and that new response criteria could show a significant difference.

Objectives: Our objective was to reanalyze EXPLORER trial's raw data using the newly described SLE response criteria.

Methods: We proceeded to a pre-specified re-analyze of EXPLORER trial's raw data. The patients included in EXPLORER study had active SLE disease defined by a British Isles Lupus Assessment Group (BILAG) score A or 2 BILAG B despite immunosuppressive regimen. Renal and neurological SLE were excluded. Patients were randomized through a 2/1 ratio to receive either two 1 gr rituximab infusions (day 0 and 15) repeated at month 6 or a placebo. Standard SLE treatment and other immunosuppressant were continued. Patients received in a stratified manner prednisone ranging from 0.5 to $1.0 \mathrm{mg} / \mathrm{kg}$ depending on disease severity at inclusion. The original efficacy criterion was a composite clinical score using BILAG at week 52.

In our new analysis, rituximab efficacy was assessed at week 52 using 4 criteria: SRI-4 (Systemic lupus erythematosus Responder Index) with and without a concomitant oral prednisone (OP) tapering objective of $<10 \mathrm{mg}$ at month 6 (SRI-4 with and without OP tapering), Lupus Low Disease Activity Score (LLDAS) and BILAG-based Combined Lupus Assessment (BICLA).

Results: Data from all 257 patients were available. There was 234 women $(91 \%)$ with a mean age of 40,3 years among which $177(69 \%)$ received hydroxychloroquine.

At week 52 , SRI-4 response rate was $27,2 \%$ in the rituximab group vs $22,7 \%$ in the placebo group $(\mathrm{p}=0.43)$; SRI-4 with OP tapering was $16 \%$ in the rituximab group vs $13.6 \%$ in the placebo group ( $p=0.62)$; LLDAS was $16 \%$ in the rituximab group vs $12.5 \%$ in the placebo group $(p=0.46)$ and BICLA was $15.4 \%$ in the rituximab group vs $15.9 \%$ in the placebo group $(p=0.91)$.

Subgroup analyses demonstrated a trend for better efficacy of rituximab compared to placebo in the subgroup of patients co-treated with methotrexate: SRI-4 of $30.6 \%$ in the rituximab group vs $12 \%$ in the placebo group $(n=74, p=0.08)$. This trend was not found in the subgroup co-treated with azathioprine: SRI-4 of $26.7 \%$ in the rituximab group vs $30.6 \%$ in the placebo group $(p=0.68)$, nor in the subgroup co-treated with mycophenolic acid: SRI-4 of $23.1 \%$ in the rituximab group vs $21.6 \%$ in the placebo group $(p=0.86)$. In the subgroup of patients with a BILAG $\mathrm{A} / \mathrm{B}$ in hematological system or vasculitis at baseline, there was a significantly higher SRI-4 response rate with rituximab: $28,6 \%$ vs $5,3 \%$ in the hematological group $(n=61, p=0,047)$ and $39,3 \%$ vs $0 \%$ in the vasculitis group $(n=38, p=0,037)$. Cumulative dose of steroids at week 52 were not statistically different: $4223 \mathrm{mg}$ in the rituximab group vs $4390 \mathrm{mg}$ in the placebo group $(p=0,65)$.

Conclusions: Our study confirms the results from the original EXPLORER study. These results might be partly related to the study's design, notably the high daily oral prednisone used. Our work suggests efficacy in subgroups with vasculitis and hematological involvement.

Disclosure of Interest: None declared

DOI: 10.1136/annrheumdis-2017-eular.1785 